\title{
Thematic Pop-Up Book as a Learning Media for Early Child- hood Language Development
}

\author{
Novi Engla Sari ${ }^{1}$ \\ Universitas Negeri Padang, Indonesia \\ Dadan Suryana $^{2}$ \\ Universitas Negeri Padang, Indonesia
}

DOI: https://doi.org/10.21009/10.21009/JPUD.131.04

Accepted: $15^{\text {th }}$ March 2019. Published: $30^{\text {th }}$ April 2019

ABSTRACT: The challenge for early childhood educators to be able to provide a touch of education that is creative, innovative, smart, and fun to develop children's intelligence optimally. This study aims to develop Thematic Pop-Up Book products as learning media for the development of Early Childhood languages. The research subjects were 15 participants in class B6 of Khaira Ummah Islamic Kindergarten in the City. The research and development used data analysis using descriptive statistical analysis techniques. The results of the validity test and the practicality of the development of Pop-Up Book media at Khaira Ummah Islamic Kindergarten in Padang City were declared valid by media experts with an average score of 95\%. Media Thematic Pop-Up Books, about Healthy and Unhealthy Foodstuffs were also declared valid by material experts with an average score of $95 \%$. The results of the trial of thematic Pop-Up book products in Khaira Kindergarten Islamic Ummah were stated as a practical medium for children with a percentage increase in the test reaching $96 \%$. Based on these results indicate that Pop-Up Book media products get a positive response from children and teachers. Media Pop-Up Book for further research can be used as a medium to improve children's cognitive, and interest in reading.

Key Words: Early Childhood Education, Language Development, Thematic Pop-up Book

(C) 2019 Early Childhood Education Post Graduate Program UNJ, Jakarta e-ISSN (Online Media): 2503-0566

P-ISSN (Print Media): 1693-1602

\footnotetext{
${ }^{1}$ Corresponding Author:

Novi Engla Sari

Universitas Negeri Padang

Jln Prof. Dr. Hamka Air Tawar Padang, Indonesia

Email: novienglasari95@gmail.com
} 


\section{INTRODUCTION}

Early childhood is 0-8 years old children are individuals who are undergoing a process of rapid and fundamental development for their next life. Early childhood has its own characteristics according to the stages of its age and is the right age in forming various potentials. Physical, spiritual, and resourceful potential and skills will develop for the better when fostered early. Therefore, to explore children's potential optimally, children can take part in learning in various types of education services based on age groups including, Child Care Centers for ages 0-6 years old, Playgroups and those who the like for ages 2-4 years, and Kindergarten / Raudhatul Athfal and the equivalent for ages 4-6 years to help stimulate all stages of growth and development of children from an early age. Early childhood education is one form of education that focuses on laying the foundation for growth and physical development, intelligence, socio-emotional, language and communication, in accordance with the uniqueness and developmental stages that are passed by early childhood. According to the Republic of Indonesia Minister of Education and Culture Regulation No. 137 of 2014 concerning the National Standards for Early Child-hood Education Article 1 paragraph 10 states that early childhood education is an effort to provide guidance to children from birth to age 6 (six) years through design education to help growth and physical and spiritual development so that children have readiness in entering further education.

Obiweluozo \& Melefa, (2014)'s research investigated strategies to improve language development as factors and foundations needed for early childhood education. The survey research design was adopted in carrying out the research and a total of seventy-one teachers were randomly sampled for this study. Three research questions guide this research. This study reveals that improving strategies for language development is very important for the achievement of children's education in early childhood education. Factors such as inadequate number of specialist language teachers, lack of resources / materials, wrong models, among others, are a barrier to the process of improving children's language development in early childhood education. The findings show that teachers have an important role in the development of children's language in early childhood education. Among other things, they must plan various activities and develop various media to attract children's interests and make them eager to learn. Based on the findings, it is recommended that the government must match policies with actions to address some of the challenges facing children in language development at the level of early childhood.

Media is needed to facilitate children in the learning process. Media plays an important role in learning, because it can create interactions between children and the material to be learned. The use of media can increase children's learning motivation, so that children's attention to learning material increases. The use of media will help educators and children in the learning process. Through the right use of media and in accordance with learning needs, the learning objectives will be easily achieved. The challenge for educators is to be able to provide a touch of education that is creative, innovative, smart, and fun so that it can develop children's intelligence optimally. So, the need for interesting and fun media for children in kindergarten is very high. Reading books can be a medium for arousing children's learning motivation and can present learning information that can be repeated according to needs. The use of reading books will help children in the learning process. Through the using of appropriate reading books and in accordance with the needs of children, the goals will be easily achieved.

Previous research shows that reading shared books promotes preschool language skills and literacy. However, not many know about the potential role of book features - specifically, the role of using word books without words compared to books with text - in children's spontaneous language 
production and teacher instructional support. In Chaparro-Moreno, Reali, \& Maldonado-Carreño (2017), copying the verbal interactions of thirteen Colombian teachers read to early childhood groups during a reading session in Spanish using wordless picture books (condition 1) and prototypical storybooks with text (condition 2). By using Computerized Language Analysis (CLAN), they found that in the condition of the wordless word book, children produced more words, words and words significantly, and the teacher showed a higher level of instructional support. Regression analysis revealed a significant relationship between children's language production and the quality of teacher feedback during teaching literacy, indicating that wordless picture books can improve children's language by increasing teaching support.

Likewise, the study conducted by (Yu, 2009) applied Erwin Panofsky's concept of the level of meaning of works of art and the image attribute framework of Corinne Jorgensen to explore the different levels of meaning felt by children in illustrated picture books. Observations, interviews, and surveys are used for data collection and analysis of content and case studies for data analysis. Thirty-one children aged three to five years were recruited from kindergartens, public libraries, and home schools participated. The findings show that children rely on their previous experience and familiarity with literary sources to reach a level of meaning. The concept of level of meaning can provide a better understanding of representing meanings for children and children's interpretation of the meaning of visual information. Referring to this study, researchers assume that the pop-up book will provide more meaningful experience than ordinary books. It is hoped that this research can inspire teachers to be more creative in making thematic pop-up books.

Today's technology has a lot of pop-up book research that is integrated with technology such as research conducted by Nazaruddin \& Efendi (2018) regarding research that illustrates the feasibility of using augmented reality pop-up books to enhance focus and object recognition for autistic children. the results of the study found that the use of pop up augmented reality books was able to increase the appreciation of autistic students towards the objects introduced to them. Indicators can be seen from increasing interest in design, duration of observation, exploration of curiosity, mastery of message content, communication when observing objects or things introduced to them. But the development of a pop-up book that is integrated with technology is still a difficult obstacle for many early childhood teachers who live in remote areas and still have difficulties with these technologies. Therefore, for early childhood teachers in Indonesia, especially in remote areas, they are required to be more creative in learning to improve aspects of children's language development.

Based on observations of researchers at Khaira Ummah Islamic Kindergarten in Padang, educators still rarely use reading books as teaching materials, reading books are still less attractive to children, so children's reading interest is low. This condition triggered researchers to develop healthy and unhealthy food reading books in the form of pop-up books. The pop-up book is expected to be a medium to arouse children's learning motivation reading books Pop-up can develop creativity and stimulate children's imagination, increase knowledge, instill children's love for reading, and be more active in learning the contents of the book. The two-dimensional display that can move in a pop-up book can present the real world in children's learning activities, so that it is in accordance with the stage of children's cognitive development which is concrete operational. The use of pop-up books will help children and educators in the learning process. Through the using of pop-up books that are appropriate and in accordance with the needs of children, the goals will be easily achieved. In addition, this book can be used independently or in groups. Therefore, researchers are interested in developing the Media Pop-Up Book Early Childhood in the Khaira Ummah Islamic Kindergarten in the City of Padang. 


\section{Early Childhood Education}

Early childhood is a unique individual and has its own characteristics according to the stages of its age. Wiyani \& Ardy, (2016, p. 99) early childhood who are growing and developing have characteristics. Multiple theories Intelligence that shows individual differences aims to make students use all their abilities, interests, and ambitious in practice. Through this theory, educators broaden their horizons in developing programs, which pay attention to individual differences and enrich the type of intelligence by using the basics in creative ways. Likewise, linguistic intelligence can be developed through various media that are effective and interesting to children (Beceren, 2010)

\section{Early Childhood Language Development}

Early childhood learns the language of the words they hear. Previous research showed greater differences in words and linguistic contexts associated with better language outcomes. One potential source is text from picture books that are read aloud to children. Many parents begin reading for their children soon after birth, so this has the potential to become an important source of linguistic input for many children. Montag, Jones, \& Smith, (2015) made a collection of 100 children's picture books. Overall, picture books contain more unique types of words than lecture words on learning for children. Furthermore, each picture book generally contains more types of unique words with conversations that are suitable for children. Text of picture books may be an important source of vocabulary for children, and these findings suggest mechanisms underlying the benefits of language related to reading for children. This research provides clues that books are always liked by children and are able to improve the development of early childhood language.

Language development for children means they only need to remember what they heard and repeat the words they heard. But as Chomsky pointed out many years ago, if this is the essence of language learning, it won't be a successful communicator. Verbal communication requires productivity, namely the ability to create unlimited sayings that have never been heard before. Some aspects of language knowledge are abstract, Chomsky's key point is that because abstraction can never be experienced directly, they must emerge from the child's own mental activity while listening to speech and this activity can be stimulated through books that appeal to children (Berman, 2018).

The importance of language especially for children in early childhood education makes and designing methods to improve children's language development becomes an important task for researchers and teachers. The use of effective language gives children the power to say what they want and need. Very important for the development of children. Language is an important key to learning that allows children to understand the world around them. Language provides an important opportunity for a child to socialize with family members and other children outside his group and to manifest himself as a person (Obiweluozo \& Melefa, 2014). Language helps children achieve their goals. Language is very important for the development of children during the early years of life, that is, early childhood. This stage is a critical and sensitive phase of life when rapid growth and development in mental, physical, emotional and social abilities emerges. findings from several recent studies indicate the importance of experience during the early years of life in subsequent developments (Ponitz, McClelland, Matthews, \& Morrison, 2009).

Reading the same book every day for a week gives children the opportunity to become truly familiar with a story because of the many readings and extended learning opportunities. Children who may not be present, are disturbed during the story, or have difficulty learning languages are 
more likely to understand the storylines and key concepts that enable them to become active participants during story time. When children get used to stories, they learn and practice important languages. skills. These include the ability to predict, understand the sequence of causal and temporal causes (i.e., learn story elements), retell stories, remember details, use vocabulary words in various contexts, answer more complex questions about stories, and learn new dialogues or social script (Wilcox, M.J., K.M, Bacon, \& Thomas, 2001). Lin, (2012) also conducted research by applying content analysis for collection, organization, and related literature analysis. Lin, (2012) also conducts research by proposing plans and designs for teaching activities with innovative teaching materials. Creating the context and characteristics needed for innovative thought teaching methods, so that student-oriented creative teaching can be a digital work of teaching materials offered to students as a reference for making their picture books. Likewise, with pop-up book research with food themes, trying to present innovative learning that attracts children's interest in learning food.

An educator in the administration of childhood education should be guided by the principles, Helmawati (2015, p. 49) The PAUD Directorate declares the principle of PAUD education including, 1) oriented to the needs of children, 2) in accordance with the child's development, 3) according to the uniqueness of each individual, 4) learning activities carried out through play, 5) child-centered learning, 6) children as active learners, 7) children learn from the concrete to abstract, from simple to complex, from movement to verbal, and from oneself to social, 8) providing an environment that sup-ports the learning process, 9) stimulating the emergence of creativity and innovation, 10) developing children's life skills, 11) using various learning resources and media in the environment, 12) children learning in accordance with its socio-cultural conditions, 13) involving the participation of parents, 14) educational stimulation is comprehensive and covers all aspects of development.

\section{Learning Media}

The study from Walter-Laager et al., (2017) investigates the effects of learning media for children from interactive word learning applications and picture cards about vocabulary acquisition of 2year-olds. His findings show that children who use the word learning application when accompanied by adults have the greatest growth in vocabulary, and those who use the application of nonaccompaniment word adult learning show the second largest growth. The less successful ones are children who play with picture cards (with or without adults). Groups of children who focus on the subject matter for the longest period of time learning the most recent words, while the group that focuses on the subject matter for the shortest period of time has the smallest growth in words. Media plays an important role in learning, because it can facilitate children in the learning process. Medium can be defined as an intermediary or introduction to the communication from the sender to the recipient. Media is one component of communication, namely as the communicator of the message to the communicant. Sahlan, Asmaun, Angga, \& Prastyo, (2016) also defines media as something that is channeling messages of funds can stimulate the mind, feelings, and willingness of the audience so that it can encourage the learning process on him. Learning media are tools that can help the learning process and function to clarify the meaning of the message delivered, so that it can achieve learning goals better and more perfectly.

An educator must be able to encourage and inspire children to be able to understand, apply, and develop rational and objective thinking patterns in response to substance of learning material. Learning goals are formulated in a simple and clear, but interesting presentation system. So, with the existence of interesting and clear learning media can encourage and inspire children to be able 
to understand and develop rational thinking patterns. Sudjana \& Rivai (2011) suggest that the benefits of learning media in student learning processes are as follows: (a) Making learning more attractive to students' attention so as foster motivation to learn. (b) Make it easier for students to understand the lesson because the meaning is clearer so that it allows students to master and achieve learning goals. (c) Teaching methods will be more varied because learning is not only obtained from the teacher's narrative so that students are not bored, and the teacher is not exhausted. (d) Students can do more learning activities because they not only listen to the teacher's description, but also other activities such as observing, doing, demonstrating, acting and others.

\section{Media Pop-Up Book}

One of the innovative medias to involve students is pop-up books. According to (Sari, 2017) a pop-up book is a book that can display images with three-dimensional effects appearing when a book is opened and gives a unique display effect when drawn in several parts. Various efforts have been made to introduce children to reading and make the reading experience more stimulating and enjoyable, especially for small children. It was found that illustrations played an important role in attracting and maintaining children's interest in reading. Therefore, children's story books are equipped with large and colorful images that describe the subject or background. Dato \& Radmilovic (2010) said that pop-up books have become a very popular choice among parents and children because the pop-up book is equipped with hinged pop-up devices that provide surprise and entertainment for children.

The pop-up book is an interactive book including the means to fold and unfold the foldable Surface and a means to entertain the reader. Funny tools are configured to appear or open when opening a foldable surface. Funny means consist of means to interact with readers, and interacting means are configured to be released from and reconnected to interactive books (Dato \& Radmilovic, 2010). The method of using pop-up book products, manufacturers are required to have readable materials and pop-up devices that are thematically related to the theme of learning. In this case the researcher included the theme of human needs, namely the theme of healthy food. Readable material includes positioning the product so that readable material can be seen, opened or expose the pop-up book device thematically related to readable material, removing pop-up devices from the product, playing with pop-up devices, and Reinstall the pop-up device for reuse

The ability to stimulate children's imagination has been limited by the pop-up books available today because the pop-up devices have been physically integrated into the book. Rahmawati \& Rukiyati (2018)'s research aims to develop a pop-up book learning media that is suitable for children aged 4-5 years and to determine the effectiveness of pop-up book learning media to improve the cognitive abilities of children aged 4-5 years. The results of the study show that pop-up books are effective for improving cognitive abilities for children aged 4-5 years. This can be seen from the results of the calculation of the paired sample t-test where the significance value of 0.00 is less than $0.05(<0.05)$, which means that the media of pop-up book learning are effective for increasing cognitive abilities for older children 4-5. Year.

Based on the analysis of the need for improved language development in early childhood in the city of Padang, the findings of previous research regarding pop-up books, researchers have a research goal to develop thematic pop-up book products according to the theme of learning. The first product designed and tested was a pop-up book to improve aspects of children's language development with the theme of healthy food. This is because there are no thematic pop-up books that can be used by early childhood teachers as learning media. 


\section{METHODS}

This type of research is research and development. According to Putra, (2011) Research and Development ( $\mathrm{R} \& \mathrm{D})$ can be defined as a research method that intentionally, systematically, aims / is directed to find, formulate, improve, develop, produce, test the effectiveness of products, models, methods / strategies/ways, services, certain procedures more superior, new, effective, efficient, productive, and meaningful. This Pop-Up Book media was developed using a model 4-D. The 4D model includes 4 stages, which are define, design, development and dissemination.

The instrument for collecting data in this study is the documentation method carried out by recording the children of Khaira Ummah Islamic Kindergarten in Padang City. The inter-view method is used as a tool for collecting data from media experts in conjunction with suggestions, criticisms and inputs, discussions were conducted with media experts, material experts and children during field trials. The questionnaire method uses a five-point response format from the Likert scale, where the alternative response is very good / very clear, good / clear, sufficient / quite clear, less / less clear, very lacking / very unclear. Da-ta analysis in this study was conducted using descriptive statistical analysis techniques. This technique will describe the results of the validity test, the practicality of the media Pop-Up Book

\section{RESULT AND DISCUSSION}

Development of media Pop-Up Book implemented with four stages, the define, design, development and dissemination. The results of activities in each of the stages are as follows:

\subsection{Define Stage}

\subsubsection{Analysis Initial-End}

\section{1) Analysis of Curriculum}

Development of media Pop-Up Book based on the curriculum of 2013. This was done essentially aimed at multimedia use so that children can achieve learning goals by basic competence. The material in basic competence 2.1-2.2- 2.3-2.5-26- 3.4 / 4.4- 3.6 / 4.6- 3.10 / 4.10- 3.11 / 4.11, the theme of my needs is the sub-theme of food and beverage, healthy living behavior, various kinds of healthy foods and drinks, unhealthy kinds of food and drinks that need to be mastered by children so that the media needs to be developed Pop-Up Book.

2) School Media Analysis

Based on researchers' observations, the media used in reading books is still minimal used by educators, reading books are still less attractive to children, low children's reading interest in reading books.

\subsubsection{Students Analysis}

Based on the analysis of students known that children age kindergarten class B at the stage of 56 years of age, the child will begin to achieve the clearer process of thinking where the cognitive abilities of its children will be able to assess, connect, and consider an event or event.

\subsubsection{Task Analysis}

Analysis of tasks is focused more on the details of Basic Competencies for healthy living behavior, healthy foods and drinks, unhealthy kinds of food and drinks. 


\subsubsection{Concept Analysis}

The main concepts that will be compiled in the media Pop-Up Book are that the Researchers will formulate the main concepts in healthy living behavior, healthy foods and drinks, unhealthy kinds of food and drinks.

\subsection{Design Stage}

At this stage there are various kinds of activities that must be carried out, among others, as follows: The first step, the researcher takes a picture of the character by taking the child's picture as the model. The finished image is then printed or printed. After printing, the next step is the cutting process using scissors and cutter then the pieces are arranged using glue. The final step is binding by combining between pages.

\subsection{Development Stage}

Media is Pop-Up Book made using used materials and is easy to find. Tools and materials: used cardboard, paperboard, glue, scissors, threads, crayons, rulers and needles. The pop-up book size design is $30 \times 40 \mathrm{~cm}$.

The following are described sections of the media Pop-Up Book that are designed:

a. Pages About Authors

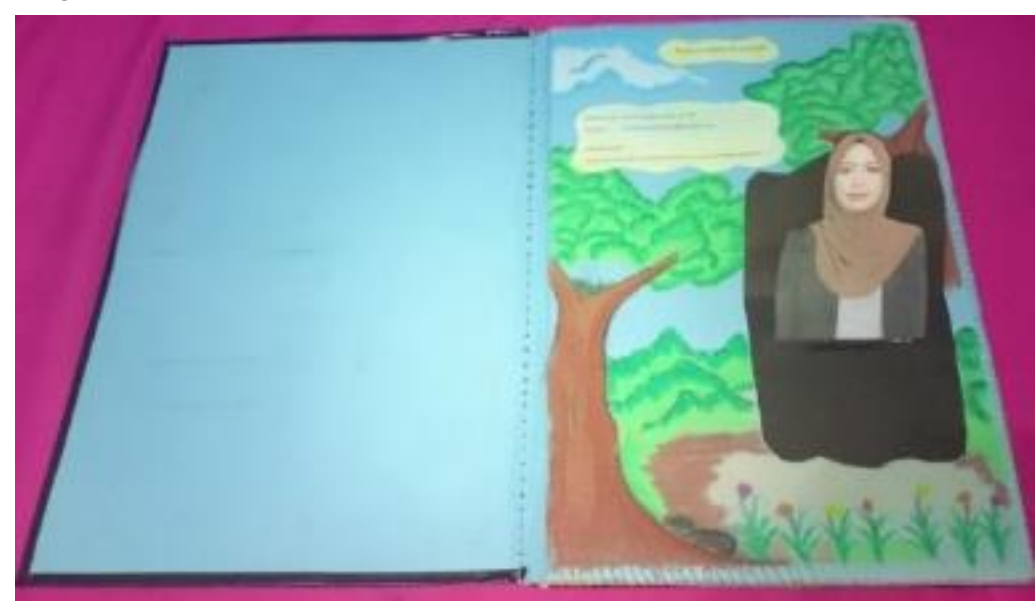

Figure 1. Pages About Authors Books 


\section{b. Page Contents}

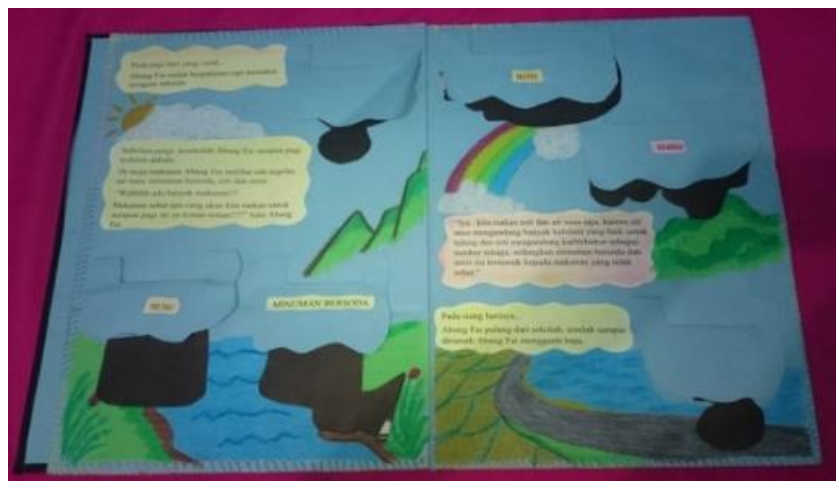

Figure 2. Pages 1 and 2 Pop-Ups closed

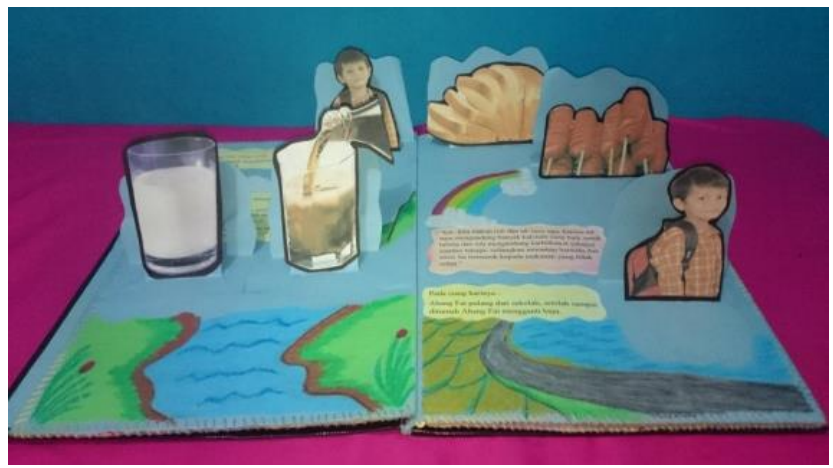

Figure 3. Pages 1 and 2 Pop-Ups Open

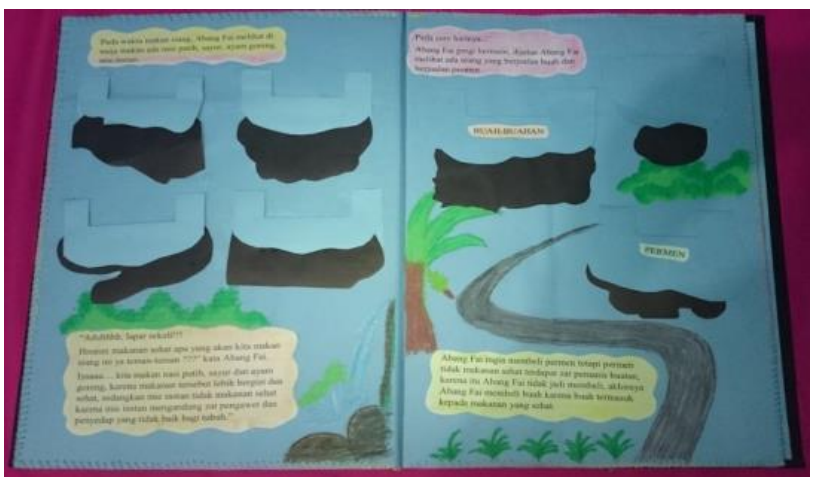

Figure 4. Pages 3 and 4 Closed Pop-Ups

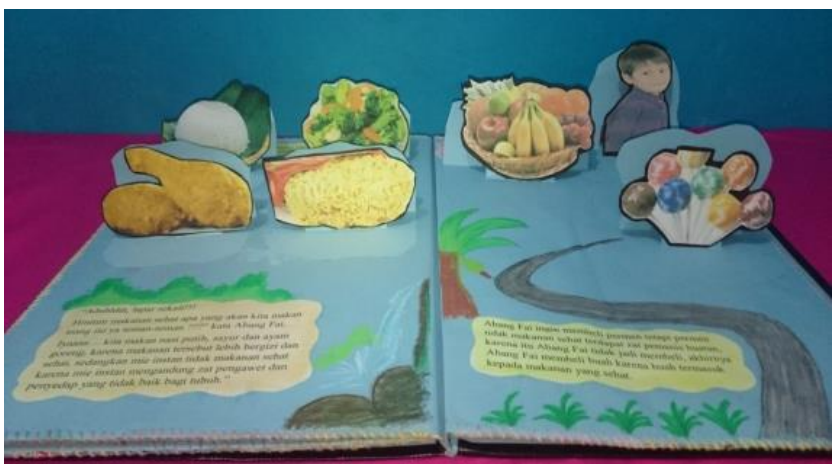

Figure 5. Pages 3 and 4 Open Pop-Ups 


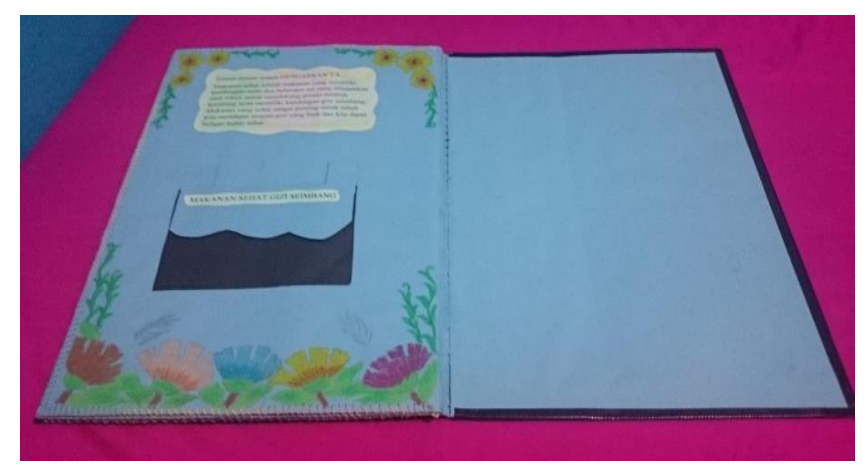

Figure 6. Page 5 Closed Pop-Ups

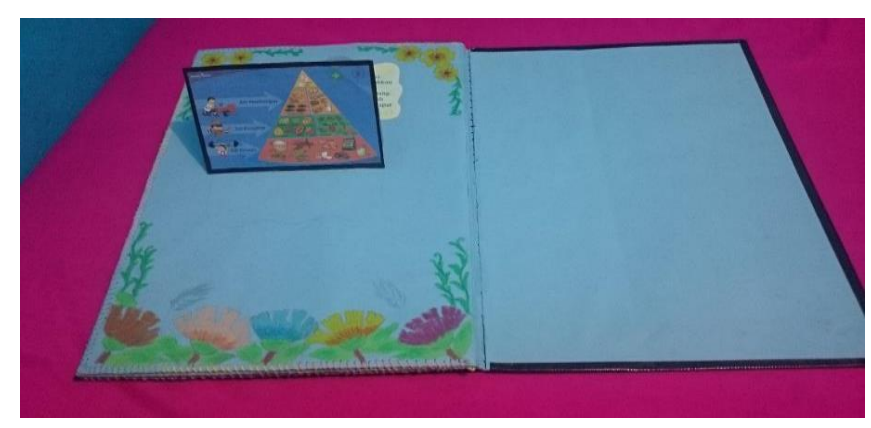

Figure 7. Page 5 Open Pop-Ups

The next step is to test the validity and practicality test. Test the validity of instructional media carried out by media experts and material experts. Validity with media experts by showing the media Pop-Up Book that has been created and then the media expert gives suggestions and comments. After that the author made a revision in accordance with the suggestions and comments of media experts.

Table 1. Analysis of Validity with Media Experts

\begin{tabular}{ccc}
\hline \multirow{2}{*}{ NO } & ASPECT OF ASSESSMENT & VALUE \\
\cline { 3 - 3 } & $\mathbf{2}$ & $\mathbf{V 1}$ \\
\hline $\mathbf{1}$ & A. DISPLAY & $\mathbf{3}$ \\
\hline & Display of attractive media & 5 \\
$\mathbf{1}$ & Selection of color background and text accordingly & 4 \\
$\mathbf{3}$ & Grouping of appropriate Images & 5 \\
\hline $\mathbf{4}$ & Text can be read clearly & 5 \\
$\mathbf{5}$ & Pictures and illustrations presented clearly & 5 \\
\hline & B. LAYOUT & 5 \\
\hline $\mathbf{6}$ & Size of book used efficiently & 5 \\
\hline $\mathbf{7}$ & Text presented adjusted to size of book & 4 \\
$\mathbf{8}$ & Accurate placement of images and contents of story & 38 \\
\hline & Total & $95 \%($ Very \\
\hline & Average assessment by media experts on all aspects & Valid) \\
\hline & Average validator rating & $95 \%$ \\
\hline
\end{tabular}


Based on the results of the table above there are 2 aspects and 8 indicators in media assessment. The results of the media expert's validation state that multimedia developed is valid. The number of media expert assessment scores is 38 . The average results of media expert evaluations are $95 \%$. The display aspect is dominated by grades 4 and 5 by media experts. Whereas the layout / layout aspect is also dominated by grades 4 and 5 by media experts.

Validity with material experts is done by showing the media Pop-Up Book that has been created and then the media expert gives suggestions and comments. After that the author made a revision in accordance with the suggestions and comments of material experts. Following analysis of validation results with material experts:

Table 2. Validity Analysis with Experts Material

\begin{tabular}{ccc}
\hline NO & ASPECT OF ASSESSMENT & VALUE \\
\hline $\mathbf{1}$ & $\mathbf{2}$ & $\mathbf{3}$ \\
\cline { 2 - 3 } $\mathbf{1}$ & The material presented is in accordance with KD & 5 \\
$\mathbf{3}$ & Material presented in accordance with the age stage of children & 5 \\
$\mathbf{4}$ & Material presented according with learning objectives & 4 \\
$\mathbf{5}$ & Improve cognitive abilities of children & 5 \\
$\mathbf{6}$ & Improve children's language skills & 5 \\
$\mathbf{n}$ & B. HABITS & 5 \\
\hline
\end{tabular}

\begin{tabular}{ccc}
\hline & C. PRESENTATION & \\
\hline $\mathbf{8}$ & The contents of the story are clearly explained & 5 \\
$\mathbf{9}$ & Systematic story order & 5 \\
$\mathbf{1 0}$ & Pictures and illustrations presented in accordance with the material & 5 \\
$\mathbf{1 1}$ & There is interaction between children and the media & 4 \\
\cline { 2 - 3 } & Amount & 52 \\
\hline & Average expert media assessment of the overall aspects & $95 \%$ (Very Valid)
\end{tabular}

Based on the table above there are 3 aspects that are assessed by material experts. In the first stage a score of 52 was obtained with an average of $95 \%$. Assessment is dominated by number 5 and number 4 .

Practical testing is carried out for children B6 Khaira Umah Islamic Kindergarten, Padang City. The following are the results of practical analysis on children based on teacher anecdotal notes:

Table 3. Practicality Analysis on Children

\begin{tabular}{cccc}
\hline No & Aspects & $\begin{array}{c}\text { Average of Practicality } \\
\text { Value (\%) }\end{array}$ & Criteria \\
\hline $\mathbf{1}$ & Ease of Use & 93 & Very Practical \\
$\mathbf{2}$ & Attraction & 98 & Very Practical \\
$\mathbf{3}$ & Understanding of Material Concepts & 96 & Very Practical \\
\hline & Total & 287 & \\
\hline & Average & 96 & Very Practical \\
\hline
\end{tabular}

The results of the practical assessment of children are stated to be very practical. Based on the 
table above, from the 3 aspects that become the assessment of media practicality in children. The values obtained are $93 \%$ ease of use, $98 \%$ attraction, and $96 \%$ understanding of material concepts. The average value obtained is $96 \%$.

\subsection{Disseminate Stage}

The dissemination stage is carried out to promote media that has been developed so that it is acceptable to users. There are 3 stages of dissemination, namely validation testing, packaging, and diffusion and adoption. In the stage of validation testing, revisions have been made in accordance with the suggestions given by the validator and have been implemented to the child. For the stage packaging, diffusion and adoption is done so that it can be used by others. However, this cannot be done due to limited facilities in conducting research so that media effectiveness tests cannot be carried out. In addition, the authors al-so package and present the results of Pop-Up Book media development products in the form of scientific works.

\section{DISCUSSION}

Pop-Up Book media development is done through 4 stages called 4D (define, design, development, and disseminate). Development of instructional media was conducted in class B6 of Khaira Ummah Islamic Kindergarten in Padang City. Making learning media using used materials and easy to find. Tools and materials: used cardboard, paperboard, glue, scissors, threads, crayons, rulers and needles. To produce appropriate learning media, a series of media expert validation, material expert validation and practicality were carried out. The series was carried out to obtain data which would then be carried out revisions or improvements to produce appropriate and useful learning media for users.

The results of media validity indicate that the Pop-Up Book media is very valid by media experts in aspects of appearance and layout. In the display aspect there are 5 indicators, namely the attractiveness of the display, the accuracy of color and text selection, the ap-propriate grouping of images, the text can be read clearly. All indicators in the display aspect are considered very valid by media experts. Arsyad, (2017, p. 172) said, multimedia aims to present information in a form that is fun, interesting, easy to understand, and clear". Based on the statement, it is evident that the development of the media must pay attention to the overall visual media. It is intended that the media developed can generate passion and interest in student learning.

In the aspect of layout, there are 3 indicators, namely the size of the book used efficiently, the text presented is adjusted to the size of the book, the accuracy of the placement of images and the contents of the story. The three indicators are considered very valid by media experts. Arsyad (2017) states that visual development must meet certain technical requirements such as visuals on slides must be clear and information or messages that are highlighted and want to be conveyed must not be disturbed by other elements. This means that all elements contained in the media must be well placed. Placement of media elements should also pay attention to the clarity of the information to be conveyed.

The results of the material validity indicate that the Pop-Up Book media is very valid by material experts in aspects of content feasibility, linguistic aspects, and presentation aspects. In the aspect of content feasibility there are indicators of the suitability of the material with basic competence (KD), the material presented in accordance with the stage of the child's age, the material presented is in accordance with the learning objectives, improving children's cognitive abilities, improving 
children's language skills. All aspects are stated to be very valid by material experts. This PopUp Book media can improve children's language and cognitive abilities. In accordance with the content of the story book about healthy and unhealthy food, it is expected that children can have healthy living behaviors and distinguish healthy and unhealthy foods.

In the language aspect there are indicators of language clarity and the suitability of the language used with KBBI. Both indicators are stated to be very valid by material experts. Therefore, the use of language in the Pop-Up Book media is very good. In the presentation aspect there are indicators related to the content of the story presented clearly, systematic story sequences, images and illustrations presented in accordance with the material, and there are interactions between children and the media. The overall indicators were very well assessed by material experts. (Safitri \& Hartati, 2016) stated that elements of proper and adequate graphics and linguistics in textbooks and multimedia are expected to motivate students. Media acts as a facilitator between educators and students in developing motivation during the learning process. For that reason, choosing the right language needs to be considered in developing the media.

Practical testing of children by the teacher. The practicality of the media is related to the practicality of using the developed media. Aspects related to practicality include ease of use, attractiveness, understanding of material concepts. Practicality was carried out on 15 class B6 Khaira Ummah Islamic Kindergarten in Padang City. The results obtained are the level of practicality of the media is very practical. This means that the media developed is very good, easy to use, attractive and provides benefits to children. In aspects of ease of use, indicators of clarity of clues, ease of use of storybook media displayed with pop-up buttons, material clarity, conformity of material with pictures of story content and images, completeness of material, and language used were considered very practical in children. On aspects of attractiveness, indicators of media appearance, color choices, and motivation to learn are also considered very practical. While aspects of understanding the concept of material are also considered very good for children. Based on this assessment means that the entire media developed is very good and feasible to use. As research conducted by Dato \& Radmilovic (2010) has proven by providing stimulation through pop-up books, children's imagination or users are increasingly stimulated and enhanced beyond normal reading experiences. After a removable device is played or interacts with it, it might be attached back to a book or card for future use which is a pleasure as a pop-up feature. This discovery can be implemented in a number of ways, and is not limited to books or cards, but can be used in various other methods of implementation

\section{CONCLUSION}

Based on the results of the research and discussion that have been conducted, there are a of things that can be concluded, namely the development of media Pop-Up Book in Khaira Ummah Islamic Kindergarten in Padang City, declared by media experts to be very valid with a 95\% average score. The media Pop-Up Book on Healthy and Unhealthy Food material is also stated to be very valid by material experts with an average rating of 95\%. The development of media Pop-Up Book at Khaira Ummah Islamic Kindergarten was stat-ed to be very practical for children by teachers with a $96 \%$ average score. Based on these results indicate that the media product Pop-Up Book received a positive response for children and teachers. Media Pop-Up Book can be used as a medium that improves children's language, cognitive, and reading interest, so that children can like reading. This research generally runs smoothly, but there are still some obstacles that researchers face. These constraints are that children cannot use the media one by one because of the 
lack of the ability of researchers to make many storybooks. But children can orderly read story books alternately. Thus, the development of the media Pop-Up Book conducted at the Khaira Ummah Islamic Kindergarten is feasible.

\section{REFERENCES}

Arsyad, A. (2017). Media Pembelajaran. PT Raja Grafindo Pursada.

Beceren, B. Ö. (2010). Determining multiple intelligences pre-school children (4-6 age) in learning process. Procedia - Social and Behavioral Sciences, 2(2), 2473-2480. https://doi.org/10.1016/j.sbspro.2010.03.356

Berman, R. A. (2018). Language Development and Literacy. Encyclopedia of Adolescence, (October), 2093-2103. https://doi.org/10.1007/978-3-319-33228-4_19

Chaparro-Moreno, L. J., Reali, F., \& Maldonado-Carreño, C. (2017). Wordless picture books boost preschoolers' language production during shared reading. Early Childhood Research Quarterly, 40, 52-62. https://doi.org/10.1016/j.ecresq.2017.03.001

Dato, A., \& Radmilovic, V. (2010). Interactive Book With Detachable, Pop-Up Device. Patent Application Publication, 1(19), 20-25. https://doi.org/US 2007/0293118A1

Helmawati. (2015). Mengenal dan Memahami PAUD. Bandung: PT Remaja Rosdakarya.

Lin, R. (2012). Creative Thinking for Picture Book Creation. IERI Procedia, 2, 30-35. https://doi.org/10.1016/j.ieri.2012.06.047

Montag, J. L., Jones, M. N., \& Smith, L. B. (2015). The Words Children Hear. Psychological Science, 26(9), 1489-1496. https://doi.org/10.1177/0956797615594361

Nazaruddin, M. A., \& Efendi, M. (2018). The Book of Pop Up Augmented Reality to Increase Focus and Object Recognition Capabilities for Children with Autism. Journal of ICSAR, 2(1), 9-14. https://doi.org/10.17977/um005v2i12018p009

Obiweluozo, E. P., \& Melefa, O. M. (2014). Strategies for Enhancing Language Development as a Necessary Foundation for Early Childhood Education. Journal of Education and Practice, 5(5), 147-155. Retrieved from www.iiste.org

Ponitz, C. C., McClelland, M. M., Matthews, J. S., \& Morrison, F. J. (2009). A Structured Observation of Behavioral Self-Regulation and Its Contribution to Kindergarten Outcomes. Developmental Psychology, 45(3), 605-619. https://doi.org/10.1037/a0015365

Putra, N. (2011). Research \& Development. Jakarta: Raja Grafindo Persada.

Rahmawati, D. I., \& Rukiyati, R. (2018). Developing Pop-Up Book Learning Media to Improve Cognitive Ability of Children Aged 4-5 Years. Atlantis Press, 249(Secret), 60-69. https://doi.org/10.2991/secret-18.2018.10

Ros, R., \& Demiris, Y. (2012). Human Behavior Understanding, 7559, 40-51. https://doi.org/10.1007/978-3-642-34014-7

Safitri, D., \& Hartati, T. A. W. (2016). Kelayakan Aspek Media dan Bahasa Dalam Pengembangan Buku Ajar dan Multimedia Interaktif Biologi Sel. Florea, 3(2), 9-14. Retrieved from https://www.google.com/url?sa=t\&rct=j\&q=\&esrc=s\&source=web\&cd=1\&ved=2ahUKE wj987v6iurhAhVm63MBHU-eCzMQFjAAegQIBhAC\&url=http\%3A\%2F\%2Fejournal.unipma.ac.id\%2Findex.php\%2FJF\%2Farticle\%2Fdownload\%2F794\%2F724\&usg =AOvVaw0vnFUWEgaIBjOUyS_L3RDB

Sahlan, Asmaun, Angga, \& Prastyo, T. (2016). Desain Pembelajaran Berbasis Pendidi-kan Karaker. Yokyakarta: Ar-Ruzz Media. 
Sari, S. A. (2017). The Development of Pop-up Book on the Role of Buffer in the Living Body. European Journal of Social Sciences Education and Research, 10(2), 213. https://doi.org/10.26417/ejser.v10i2.p213-221

Sudjana, N., \& Rivai, A. (2011). Media Pengajaran. Bandung: Sinar Baru Algensindo.

Walter-Laager, C., Brandenberg, K., Tinguely, L., Schwarz, J., Pfiffner, M. R., \& Moschner, B. (2017). Media-assisted language learning for young children: Effects of a word-learning app on the vocabulary acquisition of two-year-olds. British Journal of Educational Technology, 48(4), 1062-1072. https://doi.org/10.1111/bjet.12472

Wilcox, M.J., M., K.M, Bacon, C. K., \& Thomas, S. (2001). Enhancing Children's Language Development in Preschool Classrooms Using Literacy to Target Verbal Language Goals Enhancing Children's Language Development in Preschool Classrooms Encouraging Complex Verbal Reasoning. Arizona. Retrieved from http://icrp.asu.edu

Wiyani, \& Ardy, N. (2016). Konsep Dasar PAUD. Yokyakarta: Gava Media.

Yu, X. (2009). Levels of meaning and children: An exploratory study of picture books' illustrations. Library and Information Science Research, 31(4), 240-246. https://doi.org/10.1016/j.lisr.2009.07.003 